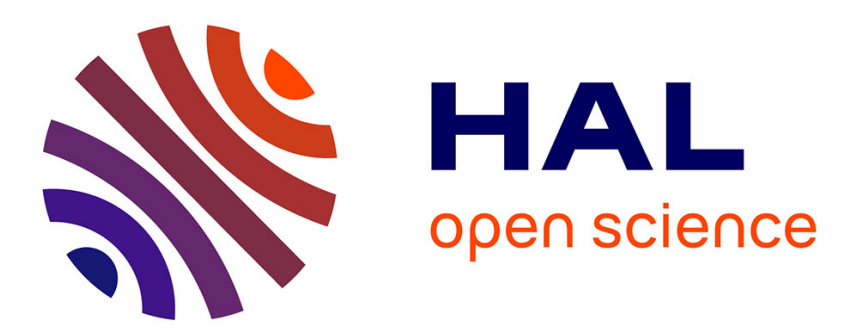

\title{
The Effect of Increasing Conceptual Challenge in Primary Science Lessons on Pupils' Achievement and Engagement
}

\author{
Jenny Mant, Helen Wilson, David Coates
}

\section{To cite this version:}

Jenny Mant, Helen Wilson, David Coates. The Effect of Increasing Conceptual Challenge in Primary Science Lessons on Pupils' Achievement and Engagement. International Journal of Science Education, 2008, 29 (14), pp.1707-1719. 10.1080/09500690701537973 . hal-00513356

\section{HAL Id: hal-00513356 \\ https://hal.science/hal-00513356}

Submitted on 1 Sep 2010

HAL is a multi-disciplinary open access archive for the deposit and dissemination of scientific research documents, whether they are published or not. The documents may come from teaching and research institutions in France or abroad, or from public or private research centers.
L'archive ouverte pluridisciplinaire HAL, est destinée au dépôt et à la diffusion de documents scientifiques de niveau recherche, publiés ou non, émanant des établissements d'enseignement et de recherche français ou étrangers, des laboratoires publics ou privés. 


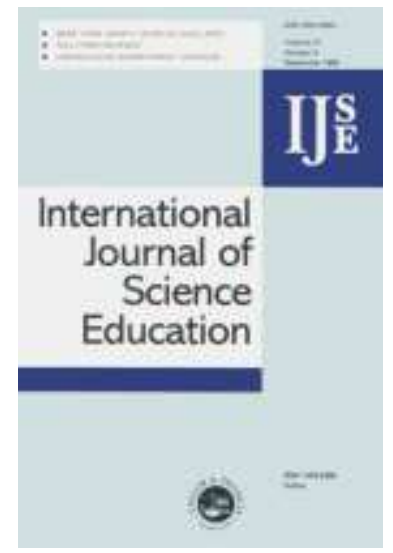

The Effect of Increasing Conceptual Challenge in Primary Science Lessons on Pupils' Achievement and Engagement

\begin{tabular}{|r|l|}
\hline Journal: & International Journal of Science Education \\
\hline Manuscript ID: & TSED-2006-0303.R1 \\
\hline Manuscript Type: & Research Paper \\
\hline Keywords: & science education, conceptual change, primary school, curriculum \\
\hline Keywords (user): & conceptual challenge, motivation, achievement \\
\hline \multicolumn{2}{|}{} \\
\hline
\end{tabular}

\section{s ScholaroNE" \\ Manuscript Central}




\section{Acknowledgements}

The authors would like to thank all of the teachers and their pupils who participated in the project and the AstraZeneca Science Teaching Trust who provided the funding. 


\title{
The Effect of Increasing Conceptual Challenge in Primary Science Lessons on Pupils' Achievement and Engagement
}

\author{
This paper reports research into the effect on 11-year-old pupils of introducing more cognitively challenging, \\ practical, and interactive science lessons. Our hypothesis was that such lessons would increase the children's \\ enthusiasm for science and their engagement with the scientific process, thereby improving educational \\ performance.
}

Schools in England are under pressure to raise achievement, as measured by the results of national tests. This has an impact on teaching, where revision of subject knowledge often dominates and can be particularly detrimental to more able pupils.

The research was a controlled trial which took place in 32 English primary schools as part of a project 'Conceptual Challenge in Primary Science'. Teachers from 16 intervention schools participated in continuing professional development (CPD) and developed science lessons that had more practical work, more discussion, more thinking and less (but more focused) writing. The proportion of pupils achieving the highest level (level 5) in the national science tests at age 11 was compared in the matched-school pairs before and after the intervention. Focus group interviews were also held with a group of pupils in each intervention school. There was a 10\% (95\% Confidence Interval 2-17\%) increase in the proportion of children achieving the top score in the intervention schools. The pupils and teachers reported greater engagement and motivation. These findings suggest that moving from rote revision to cognitively challenging, interactive science could help improve science education. They merit replication in other international settings to test their generalisability. 


\section{Introduction}

The research reported in this paper explored the effect of introducing science lessons characterized by more cognitive challenge, practical activity and discussion, rather than rote revision, on achievement and attitudes to science for 10-11 year old children.

Since the introduction of the National Curriculum (DfEE/QCA, 1999) in England in 1988, science has been one of the three core subjects taught in English primary schools. The National Curriculum determines the content of what will be taught at each Key Stage (age phase of schooling) and pupils take national tests (called Standard Assessment Tests or SATs) at the end of each Key Stage (ages 7, 11 and 14 years). School league tables of the national tests results are published each year and hence there is great pressure to raise the pupils' achievements in these tests.

However, since 2003, with the introduction of the Primary Strategy by the Department for Education and Skills (DfES, 2003), schools have been encouraged to become more creative and flexible. The above situation, with an emphasis on achievement in externally imposed tests on the one hand and a new drive for creativity on the other can be said to have led to a certain tension in the English education system. Teachers are being encouraged to be creative and to take risks in their teaching and yet schools are judged by prescribed outcome measures: national test results.

The research reported in this paper, was part of a project 'Conceptual Challenge in Primary Science', which arose in the context of, and partly in response to, the issues discussed above: schools being judged on outcomes, measured by national test scores, and at the same time being strongly encouraged to take a more 
creative and imaginative approach to teaching and learning. The project was funded by the AstraZeneca Science Teaching Trust (AZSTT). One of its aims was to test the hypothesis that the implementation of cognitively challenging, practical, and interactive lessons in Year 6 (11 year olds) science, rather than a content driven approach, would result in: 1) higher achievement in national tests; 2) increased children's enthusiasm for science and their engagement with the scientific process.

This hypothesis is supported by the work of several authors, including Montgomery (2001) and Black and Wiliam (1998) and resonates with the opening words of Excellence and Enjoyment a strategy for primary schools (DfES, 2003): 'Children learn better when they are excited and engaged...when there is joy in what they are doing, they learn to love learning'.

It is also supported by the school inspectorate OfSTED (2004) in their annual report into primary science, particularly with regard to the use of scientific enquiry, and discussion of scientific ideas: 'Teaching remains most effective where pupils are actively involved in thinking through and carrying out scientific enquiry’. (p.2)

\section{Educational Context}

\section{Decline in enthusiasm for science}

Several authors internationally have noted a decline in enthusiasm for science. In the UK Pell and Jarvis (2001) noted that this decline in enthusiasm for science appears to begin towards the end of the years in primary school. Their findings reinforced the previous findings of the Primary Assessment, Curriculum and Experience Project (PACE) (Pollard \& Triggs, 2000). PACE was a longitudinal study in the UK and considered a cohort of children as they moved from Year 1 to Year 6 from 1990 to 1996. In a comparative league table of the pupils' favoured curriculum activities, from Year 1 to Year 3, science featured, albeit in a 
fairly lowly position. However, science did not feature at all in the same league table when the children were in Years 4 to 6 . Worse still, science did feature amongst the top five of least liked subjects in Years 5 and 6. Interestingly, the children's comments in the PACE study in Key Stage 2 indicated that what made them dislike science was the weight of information presented to them which they had to learn. (Pollard \& Triggs, 2000, pp 86, 87, 95). Analysis of the data from the Planet Science (2003) student review of the science curriculum in the UK suggested that a strong negative or positive primary science experience carries through for the next six or seven years. (p.18).

In the United States the study by Piburn and Baker (1993) gave evidence of a decline in positive attitudes toward science as pupils progress through school. More recently, Sjøberg and Schreiner, (2006) noted that:

The falling recruitment to most science and technology educations is seen as a large problem in most European countries. The same tendencies are noted in the United States and in most other countries within the Organisation for Economic Co-operation and Development. (p.2)

\section{Content driven teaching}

There is a wealth of evidence that the primary science curriculum in the UK, particularly in the latter years, is perceived by many as being content laden and assessment driven. Harrison (2001) pointed out that an increasing number of teachers are teaching their Year 6 pupils to the science test and that they are teaching tips, tricks and techniques to achieve higher percentages. Black and Wiliam (1998) discussed the influence of external tests and noted that 'Such tests can dominate teachers' work and, insofar as they encourage drilling to produce right answers to short out-of-context questions, this dominance can draw teachers away from the paths to effective formative work'. (p.17) 
Murphy and Beggs (2003) noted that science is frequently being taught as a 'body of knowledge' in the final two years of primary school (p.109). The perception that science is a body of knowledge that has to be delivered in order for pupils to reach the required standards has inevitably had a major impact on teaching styles. This was summarized by the Parliamentary Office for Science and Technology (2003) which noted that:

Many teachers feel under pressure to focus on the factual content specified in the national curriculum as preparation for SATs. This can leave little time to build on children's interests; engage pupils in discussion on scientific ideas and issues; and teach scientific enquiry. (p.2)

\section{Lack of discussion}

Galton, Hargreaves, Comber and Wall (1999) cited, in their study of practice in the primary classroom in England, a figure of $50 \%$ for whole class teaching in science, which is considerably higher than that for English or mathematics. The teachers interviewed justified this emphasis on whole class activity by arguing that it was the only means of covering sufficient content to ensure that pupils performed satisfactorily in the national tests. Galton and MacBeath (2002) in their study for the National Union of Teachers (NUT) on the impact of changes on primary teachers' working lives pointed out that there is 'more whole class teaching, more pressure to move on, less time for discussion left less time to explore, to make meaning, to use illustration and anecdote to develop understanding'. (pp.51-52) Osborn, McNess and Broadfoot (2000) were similarly concerned about this trend towards whole-class teacher instruction in primary schools and suggested that an outcome of the current assessment system has been a reduction in interactive pedagogy. They went on to suggest that 'the quantity of pupils' learning experiences, rather than the quality has become the prime focus'. (p.231) 


\section{Lack of practical science}

The National Curriculum (DfEE/QCA, 1999) places a clear emphasis on practical scientific enquiry, which is part of one of the four programmes of study within the science section. However in their scoping study of primary science in the UK, Murphy and Beggs (2005) highlighted as one of their key findings that the carrying out of science investigation in the classroom was constrained and that this was partially due to concentration on national tests and lack of time. They went on to note that teachers agreed that pupils greatly enjoy practical work in science but that allowing them to carry out their own investigations was not always considered possible because of the perceived pressures on time. (p.7) The reduction in practical work was also highlighted in the Qualification and Curriculum Authority (QCA, 2005) annual report on the science curriculum and assessment which found that almost half of the primary teachers interviewed said that, because of the negative impact of class size, science experiments undertaken by pupils were limited.

Adverse consequences for the more able.

A key effect of 'teaching for the test' has been to constrain the extent to which the teaching approaches within the core curriculum areas are sufficiently challenging and stimulating (Galton. Hargreaves \& Pell, 2003). This revision and lack of cognitive challenge in the daily curriculum can be an arid process, which results in boredom and disaffection (Montgomery, 2001). Rimm and Lovance (1992) pointed out that there is a further problem with lack of challenge: 'If we don't provide a challenging environment, we are, in a de facto way, teaching our children to underachieve.' (p. 10)

It can be argued that this type of revision and subsequent lack of challenge can hinder in particular the more able pupils. In the USA Rogers (1999), in her synthesis of research findings regarding provision for the gifted 
and talented, showed that gifted students are significantly more likely to forget or mislearn science content when they must drill and review it more than two or three times. They become bored and 'switch off'.

In the literature of different countries, the meaning of the terms 'able', 'gifted' and 'talented' can vary and, as Winstanley (2004) pointed out, the myriad of definitions is alarming. Gagné, (2004) discussed the variety of meanings and highlighted the distinction between aptitude (potential) and achievement by using the term gifted to describe innate ability and talent as the expression of that potential in terms of exceptional performances in any field or fields. Porter (2005) pointed out that another way of seeing giftedness has been as a general or pervasive trait, whereas talent is ability within a specific field. (p.4)

In England generally, however, the gifted and talented are defined quite differently, and giftedness refers to academic abilities, whereas talent refers to 'non-academic' abilities, such as in art and design, music or physical education (QCA, 2001). Others, such as Freeman (1998), in her study of international research, use the terms 'very able' or 'high ability' to avoid what Freeman called 'the troublesome word, "gifted", with its implications of gifts bestowed intact from on high.'

The term 'able pupils' has been employed throughout this paper. Porter (2005) defined these pupils as 'those who have the capacity to learn at a pace and level of complexity that is significantly in advance of their age peers' (p.33). Coates and Wilson (2003) pointed out that ability in science may not be accompanied by an allround ability in other subjects.

Both Renzulli (1998) and Hewston et al. (2005) have shown that teaching strategies that cater for, and challenge, the able can be employed for all children within the normal classroom. Moreover, they 
demonstrated that this is often advantageous and can raise the performance of all students. Freeman (1998) discussed how pupils with ability can be identified through providing challenge for all within a normal classroom.

\section{Method}

Study design

The study compared the effect of a continuing professional development (CPD) initiative in classes of 10-11 year old children in 16 matched pairs of primary schools -32 schools in all. The intervention was provided to one in each pair of schools but the main outcome measure (the percentage of children achieving the highest scores (level 5) in the national science test) was measured in both schools in two consecutive years, the year before the project and the year of the project. In the 16 intervention schools only, group interviews with participating children were carried out by the science coordinator at the end of the project year.

\section{Continuing Professional Development (CPD) Intervention}

The intervention involved training two key teachers within each of the 16 intervention schools - the science coordinator and a class teacher for the 10-11 year age group (Year 6 in the UK education system). The teachers attended eight days and four twilight sessions of CPD in the university spaced at regular intervals throughout the school year. In addition the project provided funds for time for the two teachers in each school to work together to develop their teaching.

The CPD sessions explored with the participating teachers strategies for cognitively challenging, practical science lessons with plenty of space for thinking and discussion. Well-established strategies for challenge for the gifted and talented, particularly the encouragement of higher order thinking (Coates \& Wilson, 2003,) were included. However, the project promoted the use of such strategies with the whole class on an inclusive 
basis. A particular feature of the CPD was the development of 'Bright Ideas Time' discussion slots. These short focused discussions utilized a 'discussion prompt' to stimulate discussion and encourage the children to share their ideas. The 'discussion prompts' included 'odd one out', 'Big Questions' and a de Bono thinking tool called 'PMI' (De Bono, 1986). In these a scenario is set and children identify and discuss $\mathrm{P}$ - positive, $\mathrm{M}$ - minus and I - interesting features. Further details of 'Bright Ideas Time' prompts and the other strategies endorsed in the CPD can be found in Wilson \& Mant (2006).

The participating teachers practised and discussed the teaching strategies introduced during each CPD session. They then implemented them in their classes with all their pupils, followed by evaluation, further discussion and refinement in later CPD sessions. .

In summary, the CPD promoted science lessons with the following characteristics:

1) Increased time spent in discussion of scientific ideas;

2) An increased emphasis on the encouragement of higher order thinking;

3) More practical work and investigations;

4) More focused and purposeful recording by pupils, less writing

\section{Intervention schools}

The Local Government Education Authority science team for the county of Oxfordshire was asked to recommend schools for the project which would be interested in developing their science teaching and able to give the necessary commitment. The schools were all approached individually and visited by one of the researchers so that the head teacher and teachers were fully aware of the expected level of commitment. All the recommended schools were situated in small towns or rural (village) locations. The numbers on the school role ranged from 137 to 505 . The percentage of pupils from households needing financial support was lower, 
but the range of percentages of pupils registered with Special Educational Needs (SEN) similar, to the national average. Only one school had a significant number of children from ethnic minorities or with English as an additional language.

\section{Control schools}

The control schools did not receive the intervention. They were selected to match the intervention schools according to three characteristics applied sequentially: 1) percentage of pupils in the relevant 10-11 year (Year 6) age group achieving the top (level 5) grade in the national science assessment test; 2) the number of children in the year group (four strata: less than 25 pupils, 25 - 35 pupils, 36 - 60 pupils and more than 60 pupils); 3) the percentage of pupils with special educational needs (SEN). Data not in the public domain were supplied by the Local Education Authority. If no control school could be identified using this sequence the first criterion was relaxed, initially to $\pm 1 \%$ and if necessary to $\pm 3 \%$ and the sequence repeated. The final result of this matching sequence was that each control school had the same percentage of pupils achieving level $5 \pm 3 \%$ (12 out of 16 control schools either equal to or $\pm 1 \%$ ), were in the same size group, and had the same percentage of pupils with $\mathrm{SEN} \pm 5 \%$ as the participating school with which it was matched.

\section{Main outcome measure}

The main outcome measure was the proportion of children in the 10-11 year group in each school achieving a top (level 5) score in the end of year national science assessment test. These tests are taken by all children in England and are marked according to criteria defined in the National Curriculum (DfEE/QCA, 1999). These data were collected for both intervention and control schools for the year before as well as the year of the intervention. 


\section{Statistical analysis}

The change in the percentage of children in each intervention school achieving level 5 in the year of the project and in the previous year was compared with its matched control school. The distribution of these between-pair differences was described in terms of the median, mean and standard deviation. The $95 \%$ confidence interval for the mean difference was calculated based on the standard error of a proportion. To test the null hypothesis (i.e. that the changes in the percentage of pupils achieving level 5 for the project and the matched schools are the same) the observed mean difference between pairs was compared with the hypothetical value of zero using a Student t-test.

\section{Supporting qualitative outcomes}

At the end of the year, focus group interviews were conducted with children in the 16 intervention schools to ascertain their views on their science lessons during the year. Lewis (1992, p.413) suggested that group interviews are a viable and useful technique with primary-aged children. She highlighted the possibility of obtaining greater depth and breadth in responses than occur in individual interviews. She also observed that children may be less intimidated by talking in a group than when talking individually and hence the dialogue is likely to be more natural and less stilted.

These interviews were conducted by the school science coordinator, rather then their own class teacher. Training in conducting focus group interviews was given to the teachers as part of the CPD sessions. The chosen participants were four or five children identified by their class teacher as high achievers in science, based on the teacher's knowledge of the children and their test scores. The interviews were audio taped and later transcribed. The interviews were semi structured and focused on the following questions:

1) What have you enjoyed / liked about science this year? Why?; 
2) What have you not enjoyed / liked about science this year? Why?;

3) Have you noticed any changes in science this year? If so, what?

Each focus question was posed to the group as a whole and followed up with further questions, as appropriate, in order to clarify the responses. It was not possible to ascribe oral contributions to particular individuals from the tapes and the groups of pupils tended to be collaborative in their responses, hence each interview was analysed as one unit. The interview transcripts were scrutinized by two researchers and the emergent themes identified. Particular attention was given to themes which illuminated the children's perspective on their attitudes to the science lessons.

\section{Results}

Overall effect on test scores

Table 1 shows the overall effect of the project on the proportion of pupils achieving the top (level 5) test score. In the year before the project, the mean proportion of children achieving level 5 was very similar in the intervention schools (39.6\%) and the control schools (39.4\%). In the project year, the mean proportion of children achieving level 5 increased by $11.8 \%$ in the intervention schools and $2.0 \%$ in the controls schools. In only 3 of the 16 intervention schools did the proportion of children achieving level 5 fall in the project year. The median change in score was $+16.5 \%$ in intervention schools and $+2 \%$ in the control schools. [Insert table 1 about here]

\section{Comparison of matched pairs}

In the analysis of the matched pairs of schools, the intervention school did better than the control school in 12 out of 16 pairs. The median difference between the matched pairs was $+10.5 \%$. The mean difference between 
the matched pairs was $9.7 \%$ (95\% confidence interval 2.4 to $17.0 \%)$. It is statistically unlikely that a mean difference between pairs of this magnitude would occur by chance (Student's $t=2.69, p<0.02$ ).

\section{Children's perceptions of the lessons}

All the groups of children interviewed were unanimously positive about their science lessons during the year of the project and talked enthusiastically about the changes they had perceived in the lessons. The main themes emerging from the interviews identified four characteristics of the lessons to which the children attributed their increased enthusiasm and engagement: 1) more experiments and investigations; 2) new discussion activities; 3 ) more thinking for themselves; 4) less time spent writing,. The number of interviews in which the children expressed a comment relating to each theme, are shown in Table 2.

[Insert table 2 about here]

\section{Children's perceptions of the impact of the lessons on their learning}

The children articulated how they perceived these lesson characteristics had increased their engagement in learning. This is illustrated with a selection of recorded quotations.

Firstly, they demonstrated a strong awareness of how they were learning. They acknowledged that this was facilitated by the encouragement to think and the challenges provided by the teachers:

'Yeah, it's actually more challenging. I like things to be more challenging. And when it's just easy and everything's done for you and you're just to write down the results, I find it boring. I like a bit more challenge'.

Secondly, they had a clear sense of 'doing' helping 'learning'. The reasons they gave included awareness of practical involvement resulting in deeper and more lasting learning:

'I enjoyed active ... things. Because if you just get told everything that happens, it's very easy to forget. whereas if you're actually finding out what happens by yourself, it will stick in the brain more'. 
Thirdly, they explicitly stated that they liked discussing their ideas with each other, particularly working in small groups, and were able to reflect on how their own ideas had developed as they talked to each other: 'I also liked doing the think pair share. Miss C put some stuff on the board and we talked with our partner, and then we shared our thoughts with the rest of the class. (Why did you like that?) Because we got to think about different people's different ideas'.

Lastly, they appreciated that the teachers were encouraging them to think more for themselves, and in particular to use their own ideas in investigations, hence increasing their autonomy.

'I think I have had more chances to say what I am thinking and to say my own things. It has made me think for myself instead of always relying on you (the teacher) for the answer'. 'I think we have done more thinking this year. Before, we did it, but now we are asking questions first and then trying things out'.

\section{Conclusions}

The research hypothesis was that more cognitively challenging, practical, and interactive lessons in science for pupils age 10-11 would result in better achievement in national science tests and an increase in both the children's enthusiasm for science and their engagement with the scientific process. The data presented from the science national test results and the pupils' interviews support this hypothesis.

The quantitative data provide good evidence that the training intervention impacted significantly on the quality of teaching and consequent performance of the children taught. The differences between the intervention and control schools is educationally important - an estimated increase in the proportion of children achieving the top grade (level 5) in science in the end-of year national tests of between 2 and 17\%, 
with a best estimate of $10 \%$. The matching of schools appears to have been satisfactory. The national testing is independent of the investigators. The effect of the inevitable year-to-year variation in the performance of different cohorts of children was minimised in the study design but must to some extent explain the observed year-to-year variability in test results. The fact that the intervention showed an effect despite such variability increases the robustness of the result.

The pupil interviews provide further qualitative supporting evidence of engagement in science. There was also evidence of increased attainment in terms of the children's perceptions of their own learning. All of the groups of pupils interviewed, including those from the schools where the percentage of pupils achieving level 5 had decreased, commented on their increased learning and attributed this to the teaching strategies introduced by the teachers.

One of the key features of the changed lessons was more practical work. This is supported by Successive OfSTED reports that have linked the highest standards of achievement to good use of scientific enquiry (OfSTED, 2004, p.9). Another key feature was the use of strategies to increase discussion of scientific ideas and encourage pupils to think for themselves. It can be argued that the increase in scientific enquiry, where the pupils planned and carried out their own investigational work, and the accompanying climate of discussion and questioning resulted in increased scope for thinking and reasoning. Both the teachers and pupils reported a reduction in the amount of time spent writing in science lessons. The teachers focused on the purpose of recording by the pupils, so that although less was demanded it was of a higher quality. The reduction in writing released time for practical work and discussion and contributed to the positive attitudes of the pupils. 
A key question is the generalisability of our findings. The participating schools were not urban and a similar project in an inner city setting would test further the applicability of the teaching strategies. Questions also arise as to whether the teachers demonstrated increased enthusiasm for science because of the ongoing involvement in the CPD and that this was in turn a significant contributing factor to the increased enthusiasm and achievement of their pupils. The science national test results from the participating schools will need monitoring over the coming years to discover whether or not this improvement is sustained without the impetus of the CPD. This will produce data that will give information about the extent to which the project teaching strategies have become embedded in ongoing practice. However, despite these necessary reservations, the findings from this project have relevance to more than just English primary schools in rural and semi-urban areas. There is international concern about the decline in pupil attitudes to science. The findings on the type of science lessons which stimulate pupils and lead to increased scientific understanding have implications for all pupils everywhere.

In summary, the authors suggest all pupils need teaching from the earliest age that will inspire curiosity and scientific understanding. The evidence from this research points the way from a less content driven approach to one that encourages thinking through discussion and practical investigations and, at the same time, raises standards.

\section{References}

De Bono, E. (1986) Six thinking hats. Harmondsworth: Viking

Black, P. \& Wiliam, D. (1998) Inside the black box. London: King's College

Coates, D. \& Wilson, H. (2003) Challenges in primary science: Meeting the needs of able young scientists at Key Stage 2. London: NACE/Fulton 
Department for Education and Employment \& Qualifications and Curriculum Authority (DfEE/QCA) (1999) The national curriculum for England: Science. London: HMSO

Department for Education and Skills (2003) Excellence and Enjoyment: a strategy for primary schools. London: Department for Education and Skills. Retrieved 17 May, 2006 from http://www.dfes.gov.uk/primarydocument/

Freeman, J. (1998) Educating the very able: Current international research. London: HMSO Gagné, F. (2004) Transforming gifts into talents: the DMGT as a developmental theory. High Ability Studies15 (2) $119-147$

Galton, M., Hargreaves, L., Comber, C. \& Wall, D. (1999) Inside the Primary Classroom: 20 years on. London: Roultedge

Galton, M. \& MacBeath, J. with Page, C. \& Steward, S. (2002) A life in teaching? The impact of change on primary teachers' working lives. Retrieved May 15, 2006, from http://www.educ.cam.ac.uk/download/NUTreport.pdf

Galton, M., Hargreaves, L. \& Pell, T. (2003) Progress in the middle years of schooling: Continuities and discontinuities at transfer Education 3 - 13, 31 (2), 9 -18.

Harrison, S. (2001) SATs and the QCA Standards Report Primary Science Review 68, 28 - 29

Hewston, R., Campbell, R. J., Eyre, E., Muijs, D., Neelands, J., \& Robinson, W. (2005) A baseline review of the literature on effective pedagogies for gifted and talented students. The National Academy of Gifted and Talented Youth. Retrieved May 3, 2006, from http://www.nagty.ac.uk/research_centre/publications/index.aspx

Lewis, A. (1992) Group Child Interviews as a Research Tool British Educational Research Journal, 18 (4), $413-421$

Montgomery, D. (2001) Able Underachievers. London: Whurr

Murphy, C. \& Beggs, J. (2003) Children's perceptions of school science School Science Review, 84, 308 
Murphy, C. \& Beggs, J. (2005) Primary science in the UK: a scoping study. Final report to the Wellcome Trust. Belfast: St. Mary’s University College \& Queen’s University Retrieved June 6, 2006 from http://www.wellcome.ac.uk/assets/wtx026636.pdf

OFSTED (2004) Ofsted Subject Reports 2002/3: Science in primary schools. London: OfSTED

Osborn, M., McNess, E., Broadfoot, P., with Pollard, A. \& Triggs, P. (2000) What teachers do: Changing policy and practice in primary education. London and New York: Continuum

Parliamentary Office for Science and Technology (2003) Number 202, Primary science. London: Parliamentary Office for Science and Technology. Retrieved June 19, 2006 from http://www.parliament.uk/post/pn202.pdf

Pell, T. \& Jarvis, T. (2001) Developing attitude to science scales for use with children from five to eleven years. International Journal of Science Education, 23 (8), 847 - 862

Piburn, M. \& Baker, D. (1993) If I were the teacher ... qualitative study of attitude towards science. Science Education, 77, 393-406.

Planet Science, Institute of Education and Science Museum (2003). Student review of the science curriculum: Major findings, London: Planet Science. Retrieved 18 June, 2006 from http://www.planetscience.com/sciteach/review/Findings.pdf

Pollard, A. \& Triggs, P. with Broadfoot, P., Mcness, E. \& Osborn, M. (2000) What pupils say: Changing policy and practice in primary education. New York: Continuum

Porter, L. (2005) Gifted Young Children. Buckingham: Open University Press

QCA (2001) Guidance on Teaching Gifted and Talented Pupils. Retrieved 30 November 2006 from http://www.nc.uk.net/gt/general/index.htm 
QCA (2005) Science. 2004/5 annual report on curriculum and assessment December 2005 Retrieved 21 June, 2006 from

http://www.qca.org.uk/downloads/science_2004_5_annual_report_on_curriculum_and_assessment.pdf

Renzulli, J. (1998) A rising tide lifts all ships: Developing the gifts and talents of all students. Retrieved 18 June, 2006 from http://www.gifted.uconn.edu/sem/semart03.html

Rimm, S. \& Lovance, K (1992) The use of subject and grade skipping for the prevention and reversal of underachievement. Gifted Child Quarterly 36 (2), 100

Rogers, K. (2001) Best practice research summary Retrieved 15 June, 2006 from http://www.isd194.k12.mn.us/g_BPrac.htm

Sjøberg, S. \& Schreiner, C. (2006). How do learners in different cultures relate to science and technology? Results and perspectives from the project ROSE (the Relevance of Science Education). APFSLT: Asia-Pacific Forum on Science Learning and Teaching, 7(1), Foreword

Wilson, H. \& Mant, J. (2006) Creativity and excitement in science: Lessons from the AstraZeneca Science Teaching Trust project. Oxford: Oxford Brookes University

Winstanley, C. (2004) Too Clever by Half. London: Trentham Books Limited 
Table 1. Changes in the proportion of pupils achieving the top grade (level 5) in the national science test in the intervention and matched control schools.

\begin{tabular}{|c|c|c|c|c|c|c|c|}
\hline \multirow[b]{2}{*}{$\begin{array}{l}\text { Matched } \\
\text { school } \\
\text { pair }\end{array}$} & \multicolumn{3}{|c|}{ Intervention Schools } & \multicolumn{3}{|c|}{ Matched Control Schools } & \multirow{2}{*}{$\begin{array}{l}\text { Differences } \\
\text { between } \\
\text { intervention } \\
\text { and control } \\
\text { schools } \\
\left(C_{I}-C_{M C}\right)\end{array}$} \\
\hline & $\begin{array}{l}\% \text { pupils } \\
\text { level } 5 \text { in } \\
\text { previous } \\
\text { year }\end{array}$ & $\begin{array}{c}\% \text { pupils } \\
\text { level } 5 \text { in } \\
\text { intervention } \\
\text { year }\end{array}$ & $\begin{array}{c}\% \text { change } \\
\left(\mathrm{C}_{\mathrm{I}}\right)\end{array}$ & $\begin{array}{l}\% \text { pupils } \\
\text { level } 5 \text { in } \\
\text { previous } \\
\text { year }\end{array}$ & $\begin{array}{c}\% \text { pupils } \\
\text { level } 5 \text { in } \\
\text { intervention } \\
\text { year }\end{array}$ & $\begin{array}{c}\% \text { change } \\
\left(\mathrm{C}_{\mathrm{MC}}\right)\end{array}$ & \\
\hline 1 & 22 & 53 & 31 & 22 & 51 & 29 & 2 \\
\hline 2 & 24 & 31 & 7 & 23 & 41 & 18 & -11 \\
\hline 3 & 31 & 48 & 17 & 30 & 32 & 2 & 15 \\
\hline 4 & 68 & 71 & 3 & 71 & 55 & -16 & 19 \\
\hline 5 & 27 & 20 & -7 & 25 & 25 & 0 & -7 \\
\hline 6 & 38 & 57 & 19 & 38 & 53 & 15 & 4 \\
\hline 7 & 41 & 60 & 19 & 42 & 50 & 8 & 11 \\
\hline 8 & 64 & 86 & 22 & 63 & 50 & -13 & 35 \\
\hline 9 & 40 & 56 & 16 & 40 & 36 & -4 & 20 \\
\hline 10 & 38 & 59 & 21 & 38 & 30 & -8 & 29 \\
\hline 11 & 34 & 59 & 25 & 36 & 33 & -3 & 28 \\
\hline 12 & 19 & 41 & 22 & 19 & 29 & 10 & 12 \\
\hline 13 & 41 & 53 & 12 & 39 & 41 & 2 & 10 \\
\hline 14 & 63 & 44 & -19 & 63 & 36 & -27 & 8 \\
\hline 15 & 47 & 36 & -11 & 46 & 49 & 3 & -14 \\
\hline 16 & 37 & 49 & 12 & 36 & 54 & 18 & -6 \\
\hline Mean & 39.6 & 51.4 & 11.8 & 39.4 & 41.6 & 2.1 & $9.7 *$ \\
\hline
\end{tabular}

* 95\% Confidence Interval 2 to $18 \% ; \mathrm{p}<0.02$ (Student's $\mathrm{t}=2.69,15$ d.f.). 
Table 2 Changes in lessons identified by pupils during focus group interviews

\begin{tabular}{lc}
\hline \multicolumn{1}{c}{ Change identified } & $\begin{array}{l}\text { Number of interviews with responses } \\
\text { in this category }(\mathbf{n}=\mathbf{1 6})\end{array}$ \\
\hline & 16 \\
Lessons were better & 16 \\
More experiments and investigations & 13 \\
New discussion activities & 12 \\
More thinking for themselves & 11 \\
Less writing & \\
\hline
\end{tabular}

